\title{
Effects of sponge size and type on the performance of an up-flow sponge bioreactor in primary treated sewage effluent treatment
}

\author{
Tien Thanh Nguyen ${ }^{\mathrm{a}}$, Huu Hao $\mathrm{Ngo}^{\mathrm{a}^{*}}$, Wenshan Guo ${ }^{\mathrm{a}}$, \\ Archie Johnston $^{\text {a }}$ and Andrzej Listowski ${ }^{\text {b }}$ \\ ${ }^{a}$ School of Civil and Environmental Engineering, University of Technology Sydney, \\ Broadway, NSW 2007, Australia \\ ${ }^{b}$ Sydney Olympic Park Authority, 7 Figtree Drive, Sydney, NSW 2127, Australia \\ *Corresponding author, Tel: +61-2-9514-1693, Fax: + 61-2-9514-2633, \\ E-mail: h.ngo@uts.edu.au
}

\begin{abstract}
The effects of polyurethane sponge size and type on the performance of an up-flow sponge bioreactor were studied using different sponge cube sizes $(1 \times 1 \times 1 \mathrm{~cm}, 2 \times 2 \times 2 \mathrm{~cm}$ and $3 \times 3 \times 3 \mathrm{~cm})$ and types of sponge (S28-30/45R, S28-30/60R, S28-30/80R and S2830/90R). The reactors were operated under anaerobic conditions in an early stage and an aerobic condition in a latter stage. The results indicate that there was no significant difference in the organic and nutrient removal rates between sponge types. The medium size sponge $(2 \times 2 \times 2 \mathrm{~cm})$ had the best performance in terms of both biomass growth and pollutant removal. Under anaerobic condition, the COD, TN and TP removal efficiencies were up to $70 \%, 45 \%$ and $55 \%$, respectively, and significantly improved under aerobic conditions (e.g. > 90\% TOC, 95\% COD, 65\% TN and 90\% TP). The external biomass grew faster under anaerobic conditions while internal biomass was dominant under aerobic condition.
\end{abstract}


Keywords: Up-flow sponge bioreactor, Sponge size, sponge type, Organic and nutrient removal, Primary treated sewage effluent

\section{Introduction}

There is currently a growing interest in wastewater treatment using of attached growth systems (biofilm process) that are related to biomass growth on support media (Rusten et al., 1999; Tavares et al., 1994). The advantages of the attached growth system over conventional activated sludge processes (CAS) include better oxygen transfer, high nitrification rate and biomass concentrations, more effective organic removal, and relatively shorter hydraulic retention time (HRT) (Tavares et al., 1994; Ødegaard, 2000). In the attached growth system, the choice of the support media determines reactor efficiency and performance. The choice of the appropriate support media for various processes has been the subject of several research articles. The rapid and stable attachment of microorganism to a porous media surface is the most important factor for the successful application of media processes (Chae et al., 1994). The shape, size and type of material may have a strong effect on the performance of the system. The specific surface area of the support media determines the surface available for bacterial growth, while porosity determines the biofilm thickness and pore clogging (Vasiliadou et al., 2008). Sponge has been considered as an ideal attached growth media because it can act as a mobile carrier for active biomass. Polyurethane sponge and some of the other porous media have been successfully applied for attached growth systems. Yang et al. (2008) used a reticulated polyurethane sponge material as a medium in three types of rotating drum biofilters (RDB), a single layer $\mathrm{RDB}$, a multi-layer RDB, and a hybrid RDB for removal of VOCs with the efficiency over 50\%. Tawfik et al. (2006) 
successfully evaluated a combined up-flow anaerobic sludge blanket (UASB) downflow hanging sponge (DHS) system for sewage treatment. The study indicated that a combined UASB-DHS system appears an appropriate solution as a compact, low cost, and low energy requirement for sewage treatment at an average wastewater temperature of $15^{\circ} \mathrm{C}$. It comprises the most efficient integrated process and not only COD total (90\%), BOD total $(98 \%)$, TSS $(94 \%)$, ammonia (86\%) and F. coliform $(99.92 \%)$ removal but also to reduce the excess sludge production. Chuang et al. (2007) observed that the partial nitrification was satisfactorily accomplished under limited oxygen condition at around $0.5 \%$ in the gas phase $(0.2 \mathrm{mg} \mathrm{DO} / \mathrm{L})$ by using down-flow hanging sponge reactor. The system also showed a high ammonium removal rate at a maximum of 1.46 $\mathrm{kg} \mathrm{NH}_{4}{ }^{+}-\mathrm{N} \mathrm{m}$ /day, even in limited oxygen concentration. Xing et al. (1995) studied simultaneous nitrification-denitrification for the treatment of artificial sewage in two FBBR in series employing polyurethane cubes as a carrier media and observed $40 \%$ total nitrogen removal at an HRT of 4h. Deguchi and Kashiwaya. (1994) reported that the nitrification and denitrification rate coefficients of a sponge suspended biological growth reactor were 1.5 and 1.6 times respectively, higher than the coefficients of conventional activated sludge. Scarce information is however available about the effect of different sizes and types of the sponge media on the behaviour of treatment systems. A better understanding of external and internal biomass of sponge is necessary to estimate the beneficial advantage to the wastewater treatment process.

The objectives of this study are to investigate the effect of sponge conditions (sizes and types) on: (i) the removal efficiencies of organics (chemical oxygen demand COD and total organic carbon TOC) and nutrients (total nitrogen $\mathrm{TN}$ and total 
phosphorus TP) and (ii) biomass growth onto sponge surfaces and in the interior void space of the sponge cubes.

\section{Materials and methods}

\subsection{Synthetic wastewaters}

The experiments were conducted using a synthetic wastewater to avoid any fluctuation in the feed concentration and provide a continuous source of biodegradable organic pollutants such as glucose, ammonium sulfate and potassium dihydrogen orthophosphate. This was used to simulate high strength domestic wastewater (just after primary treatment process). The synthetic wastewater consists of DOC of 120-130 $\mathrm{mg} / \mathrm{L}$, COD of 330-360 mg/L, ammonium nitrogen $\left(\mathrm{NH}_{4}-\mathrm{N}\right)$ of $12-15 \mathrm{mg} / \mathrm{L}$ and orthorphosphate $\left(\mathrm{PO}_{4}-\mathrm{P}\right)$ of 3.3-3.5 mg/L (COD:N:P = 100:5:1). The composition of synthetic wastewater used in this study is shown in Table 1 (Lee et al., 2003).

\section{Table 1}

Characteristics of the synthetic wastewater

\subsection{Sponge}

Four kinds of reticulated porous polyester-urethane sponge (PUS) were used in the study, namely S28-30/45R (density of $28-30 \mathrm{~kg} / \mathrm{m}^{3}$ with 45 cells per $25 \mathrm{~mm}$ ); $\mathrm{S} 28$ 30/60R (density of 28-30 kg/m $\mathrm{m}^{3}$ with 60 cells per $25 \mathrm{~mm}$ ); S28-30/80R (density of 28$30 \mathrm{~kg} / \mathrm{m}^{3}$ with 80 cells per $25 \mathrm{~mm}$ ) and S28-30/90R (density of 28-30 kg/m $\mathrm{m}^{3}$ with 90 cells per $25 \mathrm{~mm}$ ). The sponges used in this study were purchased from Joyce Foam Pty, Australia.

\subsection{Experimental set-up}


In this study, the lab-scale sponge reactors were employed to conduct experiments under (i) anaerobic conditions and (ii) anaerobic conditions in early stage and aerobic conditions in the later stages. The sponge reactors were made of acrylic, with diameter of $10 \mathrm{~cm}$, height of $30 \mathrm{~cm}$ and the effective volume of $2 \mathrm{~L}$. The wastewater was pumped from the bottom of the reactors with a flow-rate of $10 \mathrm{~mL} / \mathrm{min}$. The organic loading rate and hydraulic retention time were $11.05 \mathrm{~kg} C O D / \mathrm{m}^{3} . \mathrm{d}$ and 2.62 hours, respectively. The sponges were packed in 6 layers inside the reactor, with 31 sponges per layer so that the total number of sponges in one reactor was 186 . The experiment was controlled under anaerobic conditions.

The three different sizes of sponge were small $(1 \times 1 \times 1 \mathrm{~cm})$, medium $(2 \times 2 \times 2$ $\mathrm{cm})$ and large $(3 \times 3 \times 3 \mathrm{~cm})$. The total weight and volume of sponges in each reactor was $13.20-13.39 \mathrm{~g}$ and $430-432 \mathrm{~cm}^{3}$ (Table 2).

\section{Table 2}

Characteristics of sponges used

\subsection{Analysis}

TOC of the influent and effluent was measured using the Analytikjena Multi N/C 2000. The analysis of COD was according to Standard Methods (APHA, AWWA, WEF, 1998). T-N and $\mathrm{PO}_{4}-\mathrm{P}$ were measured by photometric method using Spectroquant (B) Cell Test (NOVA 60, Merck). Biomass, monitored as mixed liquor volatile suspended solid, was determined according to APHA Standard Method. For measuring the external biomass of sponge, the identified number of sponge was introduced to a $200 \mathrm{~mL}$ flask with $100 \mathrm{~mL}$ of milliQ water, then was shook at $150 \mathrm{rpm}$ for $30 \mathrm{~min}$ using 
shaking incubator. After taking the external biomass, sponge was squeezed to identify internal biomass. The total biomass is the sum of internal and external biomasses.

\section{Results and discussion}

\subsection{Effect on organic removal}

Table 3 presents the total organic carbon removal efficiency during the whole operation period in the experiments with different sponge sizes under anaerobic conditions. There was a slight difference of efficiency at the different sizes of sponge during the first 15 days under anaerobic condition. The results indicate that the small, medium and large sizes were found in ascending order in terms of TOC removal efficiency. The results also indicated that the systems achieved TOC removal of over $40 \%$. This is due to sponge having the simultaneous functions of biodegradation by attached microorganisms on its surface and inner part. During the operation time, bioreaction took place due to the growth of biomass supported by the sponge. Since the simultaneous activity of biodegradation on sponge attained at its peak at day 15 , the efficiencies decreased from $40 \%$ to around $36 \%$. It can be explained by the wastewater passed through the gap between sponges without penetrating into the sponges and contacting with biomass.

COD removal efficiency was measured during the 25 days of operation (Table 3). The results indicated that both small and middle sponge size reactor had significantly higher removal efficiencies as compared to large sponge size reactor. The maximum COD removal efficiencies of small and middle sizes at day 10 were 54.9 and $69.9 \%$, respectively. Meanwhile, the removal efficiency of the large sponge size was 
only $28.8 \%$ after 3 days, followed by a steady state. Nevertheless, the removal efficiency decreased dramatically in both small and medium sponge size reactors after 15 days, reaching almost the same value of large size of approximately $30 \%$.

\section{Table 3}

TOC, COD, TN, TP removal efficiencies for different sizes of sponge under anaerobic condition

When varying with different sponge types, there was no significant difference in terms of TOC and COD removal efficiency (Fig. 1). The efficiencies of 40.1-41.8\% TOC and 29.4-31.9\% COD removals were achieved after 10 days of operation under anaerobic condition. The COD removal efficiency was higher in the small sponge size reactor as the larger number of sponges in the reactor (430 sponges) resulting in higher effective surface area. There was a dramatic increase when the condition changed from anaerobic to aerobic. The results clearly indicate that the TOC removal efficiencies were around $90 \%$ under aerobic conditions, whilst only $40.1-41.8 \%$ was achieved under anaerobic conditions. The same trend was also observed in case of COD removal, with the efficiencies over $95 \%$. This clearly shows that aerobic sponge reactor has better performance than an anaerobic sponge reactor in terms of organic removal.

Fig. 1. TOC and COD removal efficiencies of different types of sponge (average influent $\mathrm{DOC}=130 \mathrm{mg} / \mathrm{L}$, average influent $\mathrm{COD}=330 \mathrm{mg} / \mathrm{L}$, sponge size $=1 \times 1 \mathrm{x} 1$ $\mathrm{cm}$, number of sponge in each reactor $=186$, influent feeding rate $=10 \mathrm{~mL} / \mathrm{min}$, organic loading rate $=11.05 \mathrm{~kg} \mathrm{COD} / \mathrm{m}^{3} . \mathrm{d}$, hydraulic retention time $=2.62$ hours)

\subsection{Effect on nutrient removal}

Table 3 shows total nitrogen and total phosphorus removal efficiencies at different sponge sizes under anaerobic conditions. The peaks of efficiencies were observed at day 3 in the large sponge size reactor, and at day 10 in both small and medium sponge size reactor. The highest TN and TP removal efficiencies increased 
with sponge size (e.g. $24.3 \% \mathrm{TN}$ and $28.5 \% \mathrm{TP}, 34.9 \% \mathrm{TN}$ and $42.2 \% \mathrm{TP}$, and $44.2 \%$ $\mathrm{TN}$ and 55.4\% TP in large, small and medium sponge size reactors, respectively).

Table 3

TOC, COD, TN, TP removal efficiencies for different sizes of sponge under anaerobic condition

The results from the different experiments for types of sponge are shown in Fig.

2. In the early stage under anaerobic conditions, the highest removal efficiencies were achieved at day 10 , with the TN removal efficiencies ranging from $22.7 \%(60 \mathrm{R}, 80 \mathrm{R}$ and $90 \mathrm{R})$ to $29.5 \%$ (45R). There was a slight decrease in removal efficiencies at day 15 in both TN and TP. It almost dropped by approximately $50 \%$ in the case of TP removal, from $29.4-32.0 \%$ to $12.7-16.8 \%$. For TN removal, the efficiencies were only from $14.8 \%(45 \mathrm{R})$ to $20.4 \%$ (60R). After 15 days operation under anaerobic, the condition was changed to aerobic by supplying air from the bottom. There was a significant increase in both TN and TP removal efficiencies. The maximum value of $66.5 \%$ (45R, day 18), 66.5\% (60R, day 35), 71.1\% (80R, day 30) and 67.1\% (90R, day35) was achieved in TN removal efficiencies under aerobic condition. This increase is explained by the occurring of the nitrification process under aerobic condition, which stimulates the significant removal of ammonium nitrogen. For TP removal efficiencies, the values were $98.6 \%$ (45R, day 16), $97.8 \%$ (60R, day 16), 99.6\% (80R, day 25$)$ and $89.7 \%$ (90R, day 16). There was a slight decrease in efficiencies at day 20; however it recovered to the normal value after 35 days operation, with the efficiencies of $62.9-68.2 \%$ of TN removal and $74.8-80.0 \%$ of TP removal.

Fig. 2. $\mathrm{TN}$ and TP removal efficiencies (average initial nitrogen $=18 \mathrm{mg} / \mathrm{L}$, average initial phosphorus $=3.2 \mathrm{mg} / \mathrm{L}$, sponge size $=1 \times 1 \times 1 \mathrm{~cm}$, number of sponge in each reactor $=186$, influent feeding rate $=10 \mathrm{~mL} / \mathrm{min}$, organic loading rate $=11.05 \mathrm{~kg}$

$\mathrm{COD} / \mathrm{m}^{3} . \mathrm{d}$, hydraulic retention time $=2.62$ hours) 


\subsection{Effect on biomass growth}

Table 4 shows the ratio between internal and external biomass growth on sponges. The results clearly indicated the amount of internal biomass was much higher than that of the external biomass, especially during the first 5 days. At day 3, the ratios in small, medium and large sponge sizes were $15.5,41.0$ and 44.0 , respectively. The lower ratio observed in small size sponge was due to its relatively high surface area. These ratios also demonstrated that, in the initial phase, biomass tended to grow inside rather than outside of the sponge. In the next 2 days, the proportion decreased dramatically, from 15.5 to 4.8 in small sponge size, from 41.0 to 9.1 in medium sponge size, and from 44 to 17.5 in large sponge size. After 15 days, it remained stable around 2.6-6.2 in all columns, however the lowest value was also observed in small sponge size.

\section{Table 4}

The ratio between internal and external biomass in the experiment of different sizes of sponge under anaerobic condition

The addition of internal and external biomass was then calculated based on the weight of sponge to get the total biomass value (Fig. 3). During the first 5 days, biomass on small sponge size grew faster than that of the other sizes; however, the biomass started decreasing in small sponge size from day 15 . It was gradually slumped from 79.3 to 74 and to $63.9 \mathrm{mg}$ biomass/g sponge at day 15,20 and 25 , respectively. Meanwhile the total biomass of medium and large size sponge kept increasing, reached $100 \mathrm{mg}$ biomass/g sponge in medium sponge size at 25 days. The decrease of total biomass in small sponge size could be explained by the degradation of biomass grown on the large surface area of sponge. The highest value of total biomass growth on 
medium sponge size since day 10 demonstrated the higher removal efficiencies in COD, $\mathrm{TN}$ and TP removal as compared to the small and large sponge size.

Fig. 3. Profiles of total biomass of sponge for different sizes of sponge (sponge volume $=430-432 \mathrm{~cm}^{3}$, influent feeding rate $=10 \mathrm{~mL} / \mathrm{min}$, organic loading rate $=11.05 \mathrm{~kg}$ $\mathrm{COD} / \mathrm{m}^{3} . \mathrm{d}$, hydraulic retention time $=2.62$ hours)

The profile of external biomass variation with different sponge types is given in Fig. 4a. In the early stage, under anaerobic condition, the highest value of external biomass was achieved in S28-30/60R with $30.6 \mathrm{mg}$ biomass/ g sponge, whereas only $16.2 \mathrm{mg}$ biomass/ $\mathrm{g}$ sponge in S28-30/90R, $22.3 \mathrm{mg}$ biomass/ $\mathrm{g}$ sponge in S28-30/80R and $25.9 \mathrm{mg}$ biomass/ $\mathrm{g}$ sponge in S28-30/45R. The amount of external biomass dramatically decreased when the condition was changed from anaerobic to aerobic. It was only $0.6 \mathrm{mg}$ biomass/ g sponge (60R), $1.5 \mathrm{mg}$ biomass/ g sponge (90R), $2.6 \mathrm{mg}$ biomass/ g sponge (80R) and $3.9 \mathrm{mg}$ biomass/ g sponge (45R) at day 18 . It was then slightly rose after 25 and 30 days operation, at day 35 the external biomass ranged from $1.9 \mathrm{mg}$ biomass/ g sponge (90R) to $3.3 \mathrm{mg}$ biomass/ g sponge (60R). These results proved that under anaerobic conditions the external biomass growth on surface area of polyurethane sponge has a higher value than that under aerobic conditions. Fig. 4b shows the variation of the internal biomass in different types of sponge under anaerobic and aerobic conditions. In the early stage, the reduced amount of biomass was produced inside the sponge as compared to the second stage. The highest value of internal biomass was observed in S28-30/90R with $33.8 \mathrm{mg}$ biomass/g sponge, followed by S28-30/60R (27.5 mg biomass/ g sponge), S28-30/80R (22.7 mg biomass/ g sponge) and S28-30/45R (18.7 mg biomass/ g sponge). The significant higher amount of internal biomass was achieved when the condition was changed to aerobic. The internal biomass was slightly accumulated inside the sponge; for instance, it increased from $106.1 \mathrm{mg}$ 
biomass/ g sponge to 109.3, 149.5 and $195.6 \mathrm{mg}$ biomass/ g sponge in day 18, 25, 30, 35 in sponge S28-30/90R, respectively. After 35 days of operation, the largest amount of internal biomass was recorded at sponge S28-30/90R with the value of $195.6 \mathrm{mg}$ biomass/g sponge, and the lowest amount was at sponge S28-30/60R with the value of $137.6 \mathrm{mg}$ biomass/ $\mathrm{g}$ sponge. Total biomass, the sum of external and internal biomass, is given in Fig. 4c. At the end of the first stage, the total biomass of sponge S28-30/60R (197.5 mg biomass/ $\mathrm{g}$ sponge) was relatively higher than the others $(140.9-168.2 \mathrm{mg}$ biomass/ g sponge). In aerobic conditions, there was a relatively proportion between internal biomass and external biomass because the amount of internal biomass was much higher than external biomass.

Fig. 4. Biomass variation for different types of sponge, (a) external biomass, (b) internal biomass, (c) total biomass (sponge size $=1 \times 1 \times 1 \mathrm{~cm}$, number of sponge in each reactor $=186$, influent feeding rate $=10 \mathrm{~mL} / \mathrm{min}$, organic loading rate $=11.05 \mathrm{~kg}$ $\mathrm{COD} / \mathrm{m}^{3} . \mathrm{d}$, hydraulic retention time $=2.62$ hours)

\section{Conclusions}

In conclusions, medium size sponge $(2 \times 2 \times 2 \mathrm{~cm})$ performed better than smaller and larger size sponges in terms of COD, TN and TP removal. Under anaerobic conditions, the external biomass grew faster and the medium size sponge had more attached growth biomass and effectively removed COD, TN and TP. There was no significant difference between the four types of sponge (S28-30/45R, S28-30/60R, S28-30/80R and S2830/90R) in terms of organic and nutrient removal. The internal biomass was dominant in the sponge reactor under aerobic condition which had much better performance than that of anaerobic condition.

\section{Acknowledgment}


This study was funded by Australian Research Council (ARC) Industry Linkage Grant (LP0882089).

\section{References}

Ajay, P., Zhu, J., Nakhla, G., 2006. Simultaneous carbon, nitrogen and phosphorous removal from municipal wastewater in a circulating fluidised bed bioreactor. Chemosphere 65, 1103-1112.

APHA, AWWA, and WEF, 1998. Standard Methods for the examination of Water and Wastewater, $20^{\text {th }}$ edition. American Public Health Association, Washington, DC.

Chae, K.J., Kim, S.M., Park, H.D., Yim, S.H., Kim, I.S., 2008. Development of pseudoamphoteric sponge media using polyalkylene oxide-modified polydimethylsiloxane (PDMS) for rapid start-up of wastewater treatment plant. Chemosphere 71, 961-968.

Chuang, H.P., Ohashi, A., Imachi, H., Tandukar, M., Harada, H., 2007. Effective partial nitrification to nitrite by down-flow hanging sponge reactor under limit oxygen condition. Water research 41, 295-302.

Deguchi, H., and Kashiwaya, M., 1994. Study on nitrified liquor recycling process operations using polyurethane foam sponge cubes as a biomass support medium. Water Science and Technology 30, 143-149.

Fox, P., Suidan, M.T., Bandy, J.T., 1990. A comparison of media types in acetate fed expanded-bed anaerobic reactors. Water resource 24, 827-835.

Fu, Z., Yang, F., Zhou, F., Xue, F., 2008. Control of COD/N ratio for nutrient removal in a modified membrane bioreactor treating high strength wastewater. Bioresource technology 100, 136-141. 
Guo, W.S., Vigneswaran, S., Ngo, H.H, Xing, W., Goteti, P., 2008. Comparison of the performance of submerged membrane bioreactor and submerged membrane adsorption bioreactor. Bioresource technology 99, 1012-1017.

Kim, D., Kim, K.Y., Ryu, H.D., Min, K.K., Lee, S.I., 2009. Long term operation of pilot scale biological nutrient removal process in treatment municipal wastewater. Bioresource technology 100, 3180-3184.

Lee, W., Kang, S., Shin, H., 2003. Sludge characteristics and their contribution to microfiltration in submerged membrane bioreactors. Journal of Membrane Science 216, 217-227.

Loukidou, M.X., Zouboulis, A.I., 2001. Comparison of two biological treatment processes using attached-growth biomass for sanitary leachate treatment. Environmental pollution 111, 273-281.

Moore, R., Quarmby, R., Stephenson, T., 2000. The effect of media size on the performance of biological aerated filters. Water resource 35, 2514-2522.

Nickel, M., Leininger, S., Proll, G., Brummer, F., 2001. Comparative studies of two potential methods for the biotechnological production of sponge biomass. Journal of biotechnology 92, 169-178.

Ngo, H.H., Guo, W.S., Xing, W., 2008. Evaluation of a novel sponge-submerged membrane bioreactor for sustainable water reclamation. Bioresource technology 99, $2429-2435$.

Ødegaard, H., 2000. Advanced compact wastewater treatment based on coagulation and moving bed biofilm processes. Water Science Technology 42, 33-48. 
Petruccioli, M., Duarte, J.C., Federici, F., 2000. High rate aerobic treatment of winery wastewater using bioreactors with free and immobilized activated sludge. Journal of bioscience and bioengineering 90, 381-386.

Rusten, B., Johnson, C.H., Devall, S., Davoren, D., Cashion, B.S., 1999. Biological pretreatment of chemical plant wastewater in high rate moving bed biofilm reactor. Wat. Sci. Tech 39, 257-264.

Show, K.Y., Tay, J.H., 1999. Influent of support media on biomass growth and retention in anaerobic filters. Water research 33, 1471-1481.

Sombatsompop, K., Visvanathan, C., Aim, R.B., 2006. Evaluation of biofouling phenomenon in suspended and attached growth membrane bioreactor systems. Desalination 201, 138-149.

Tavares, C.R.G., Russo, C., Anna, G.L., 1994. Aerobic treatment of wastewater in three phases fluidised bed bioreactor: a comparison of two types of polymeric supports. Envi. Tech 15, 687-693.

Tawfik, A., Ohashi, A., Harada, H., 2006. Sewage treatment in a combined up-flow anaerobic sludge blanket (UASB)-down-flow hanging sponge (DHS) system. Biochemical Engineering Journal 29, 210-219.

Vasiliadou, I.A., Karanasios, K.A., Pavlou, S., Vayenas, D.V., 2008. Experimental and modelling study on drinking water hydrogenotrophic denitrification in packed-bed reactors. Journal of Hazardous Materials 165, 812-824.

Wang, J., Wu, C., Chen, J., Zhang, H., 2006. Denitrification removal of nitric oxide in a rotating drum biofilter. Chemical Engineering Journal 121, 45-49. 
Xie, W., Wang, Q., Song, G., Kondo, M., Teraoka, M., Ohsumi, Y., Ogawa, H.I., 2004. Upflow biological filtration with floating filter media. Process biochemistry 39, 765770.

Xing, X.H., Shiragami, N., Unno, H., 1995. Simultaneous removal of carbonaceous and nitrogenous substance in wastewater by a continuous-flow fluidized-bed bioreactor. J. Chem. Eng. Jpn. 28, 525-530.

Yang, C., Suidan, M.T., Zhu, X., Kim, B.J., Zeng, G., 2008. Effect of gas empty bed contact time on performances of various types of rotating drum biofilters for removal of VOCs. Water research 42, 3641-3650.

Zhao, Q., Wang, B., 1995. Evaluation on a pilot-scale attached-growth pond system treating domestic wastewater. Water resource 30, 242-245. 
Table 1

Characteristics of the synthetic wastewater

\begin{tabular}{ccc}
\hline Compound & Chemical formula & $\begin{array}{c}\text { Concentration } \\
(\mathrm{mg} / \mathrm{L})\end{array}$ \\
\hline Organics and nutrients & $\mathrm{C}_{6} \mathrm{H}_{12} \mathrm{O}_{6}$ & 280 \\
Glucose & $\left(\mathrm{NH}_{2}\right)_{2} \mathrm{SO}_{4}$ & 142 \\
Ammonium sulfate & $\mathrm{KH}_{2} \mathrm{PO}_{4}$ & 26 \\
Potassium phosphate & & \\
Trace nutrients & & \\
Calcium chloride & $\mathrm{CaCl}_{2} \cdot 2 \mathrm{H}_{2} \mathrm{O}$ & 0.368 \\
Magnesium sulfate & $\mathrm{MgSO}_{4} \cdot 3 \mathrm{H}_{2} \mathrm{O}$ & 5.070 \\
Manganese chloride & $\mathrm{MnCl}_{2} \cdot 4 \mathrm{H}_{2} \mathrm{O}$ & 0.275 \\
Zinc sulfate & $\mathrm{ZnSO}_{4} \cdot 7 \mathrm{H}_{2} \mathrm{O}$ & 0.440 \\
Cupric sulfate & $\mathrm{CuSO}_{4} \cdot 5 \mathrm{H}_{2} \mathrm{O}$ & 0.391 \\
Cobalt chloride & $\mathrm{CoCl}_{2} \cdot 6 \mathrm{H}_{2} \mathrm{O}$ & 0.42 \\
Sodium molybdate & $\mathrm{Na}_{2} \mathrm{MoO}_{4} \cdot 2 \mathrm{H}_{2} \mathrm{O}$ & 1.26 \\
dihydrate & $\mathrm{FeCl}_{3}$ & 1.45 \\
Ferric chloride anhydrous & & 30 \\
Yeast extract & &
\end{tabular}


Table 2

Characteristics of sponges used

\begin{tabular}{cccccc}
\hline Reactor & $\begin{array}{c}\text { Size of } \\
\text { sponge } \\
(\mathrm{cm})\end{array}$ & $\begin{array}{c}\text { Number of } \\
\text { sponge }\end{array}$ & $\begin{array}{c}\text { Total weigh } \\
\text { of sponge }(\mathrm{g})\end{array}$ & $\begin{array}{c}\text { Total volume } \\
\text { of sponge } \\
\left(\mathrm{cm}^{3}\right)\end{array}$ & $\begin{array}{c}\text { Total surface } \\
\text { area of sponge } \\
\left(\mathrm{cm}^{2}\right)\end{array}$ \\
\hline 1 & $1 \times 1 \times 1$ & 430 & 13.39 & 430 & 2580 \\
2 & $2 \times 2 \times 2$ & 54 & 13.20 & 432 & 1296 \\
3 & $3 \times 3 \times 3$ & 16 & 13.37 & 432 & 864 \\
\hline
\end{tabular}


Table 3

TOC, COD, TN, TP removal efficiencies for different sizes of sponge under anaerobic condition

\begin{tabular}{ccccc}
\hline $\begin{array}{c}\text { Removal } \\
\text { efficiency } \\
(\%)\end{array}$ & Day & $\begin{array}{c}\text { Small size sponge } \\
1 \times 1 \times 1 \mathrm{~cm}\end{array}$ & $\begin{array}{c}\text { Medium size } \\
\text { sponge } \\
2 \times 2 \times 2 \mathrm{~cm}\end{array}$ & $\begin{array}{c}\text { Large size sponge } \\
3 \times 3 \times 3 \mathrm{~cm}\end{array}$ \\
\hline TOC & 3 & 29.0 & 24.1 & 21.0 \\
& 10 & 39.7 & 34.3 & 32.3 \\
& 15 & 43.6 & 44.0 & 40.9 \\
\hline COD & 3 & 22.6 & 23.9 & 28.8 \\
& 10 & 54.9 & 69.9 & 23.3 \\
\hline TN & 15 & 25.9 & 23.1 & 24.2 \\
\hline & 3 & 16.2 & 18.9 & 23.3 \\
& 10 & 34.9 & 44.2 & 22.7 \\
\hline TP & 15 & 18.2 & 18.2 & 26.0 \\
& 10 & 25.0 & 24.7 & 21.5 \\
& 15 & 42.2 & 55.4 & 28.5 \\
\hline
\end{tabular}




\section{Table 4}

The ratio between internal and external biomass in the experiment of different sizes of sponge under anaerobic condition

\begin{tabular}{cccc}
\hline Day & $\begin{array}{c}\text { Small size sponge } \\
1 \times 1 \times 1 \mathrm{~cm}\end{array}$ & $\begin{array}{c}\text { Medium size sponge } \\
2 \times 2 \times 2 \mathrm{~cm}\end{array}$ & $\begin{array}{c}\text { Large size sponge } \\
3 \times 3 \times 3 \mathrm{~cm}\end{array}$ \\
\hline 3 & 15.5 & 41.0 & 44.0 \\
5 & 4.8 & 9.1 & 17.5 \\
10 & 1.8 & 5.0 & 9.3 \\
15 & 6.4 & 7.9 & 3.2 \\
20 & 2.7 & 4.8 & 4.0 \\
25 & 2.6 & 5.3 & 6.2 \\
\hline
\end{tabular}




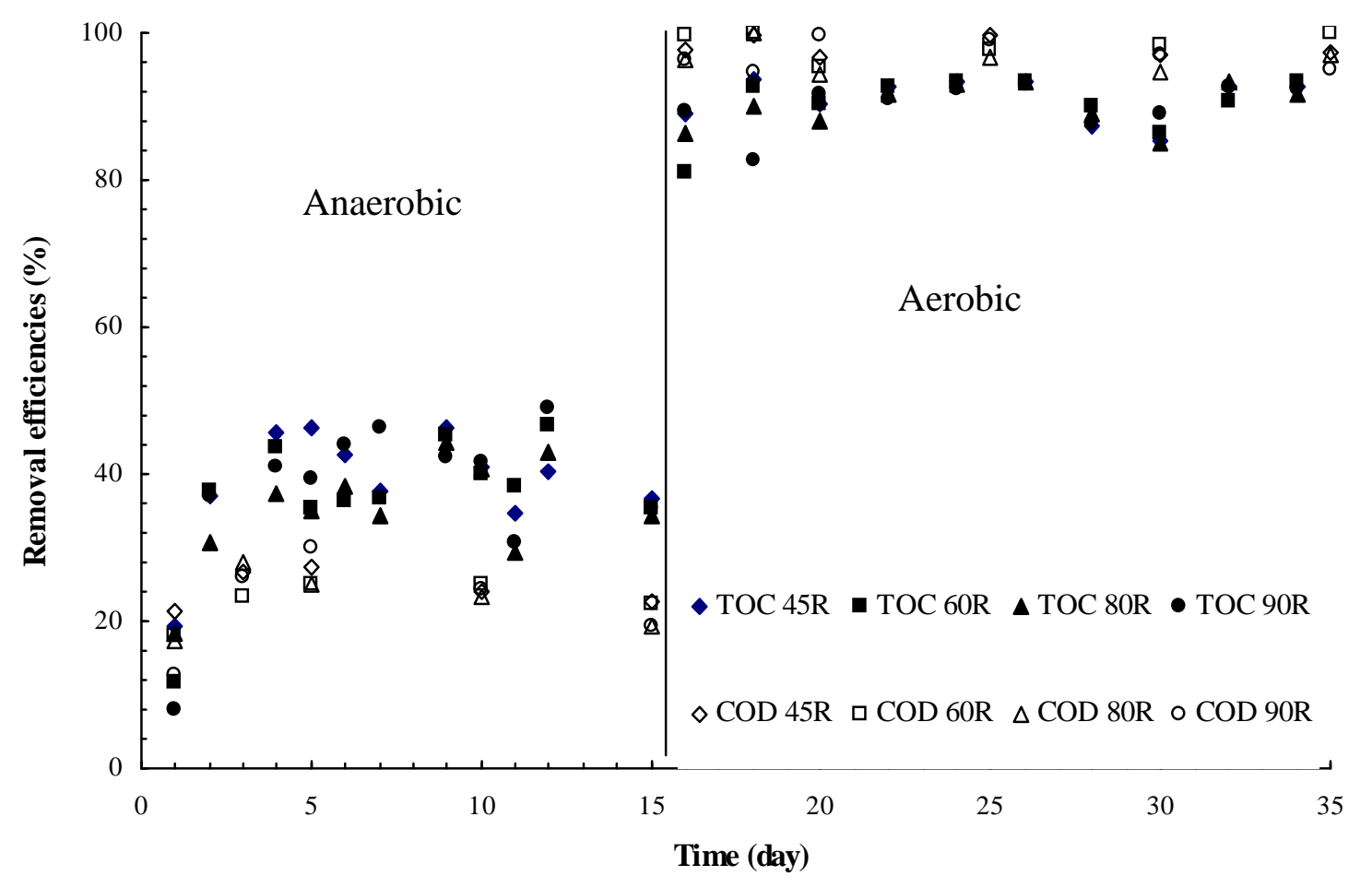

Fig. 1. TOC and COD removal efficiencies of different types of sponge (average influent $\mathrm{DOC}=130 \mathrm{mg} / \mathrm{L}$, average influent $\mathrm{COD}=330 \mathrm{mg} / \mathrm{L}$, sponge size $=1 \times 1 \times 1$ $\mathrm{cm}$, number of sponge in each reactor $=186$, influent feeding rate $=10 \mathrm{~mL} / \mathrm{min}$, organic loading rate $=11.05 \mathrm{~kg} \mathrm{COD} / \mathrm{m}^{3} . \mathrm{d}$, hydraulic retention time $=2.62$ hours) 


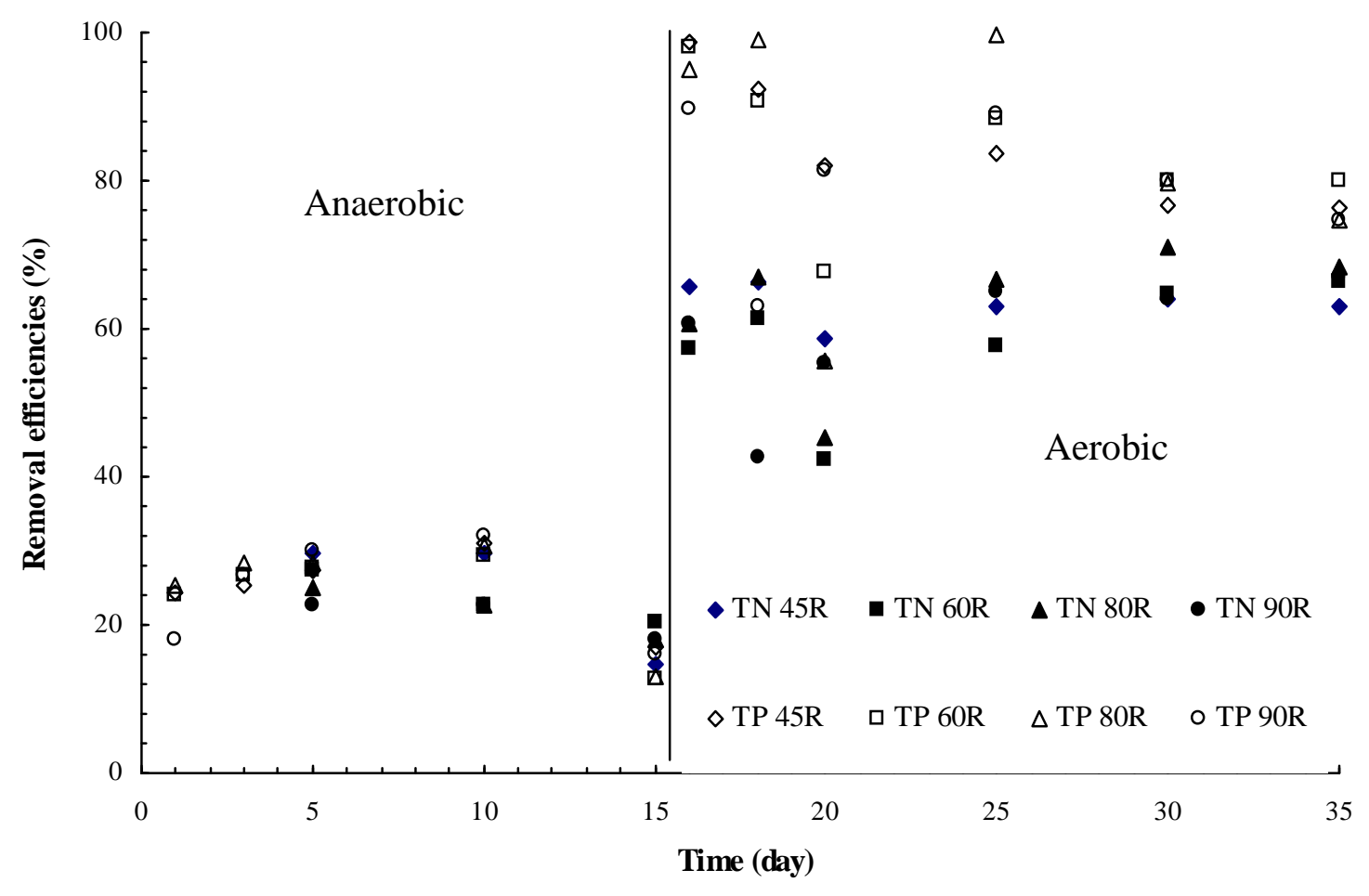

Fig. 2. $\mathrm{TN}$ and $\mathrm{TP}$ removal efficiencies (average initial nitrogen $=18 \mathrm{mg} / \mathrm{L}$, average initial phosphorus $=3.2 \mathrm{mg} / \mathrm{L}$, sponge size $=1 \times 1 \times 1 \mathrm{~cm}$, number of sponge in each reactor $=186$, influent feeding rate $=10 \mathrm{~mL} / \mathrm{min}$, organic loading rate $=11.05 \mathrm{~kg}$ $\mathrm{COD} / \mathrm{m}^{3} \cdot \mathrm{d}$, hydraulic retention time $=2.62$ hours) 


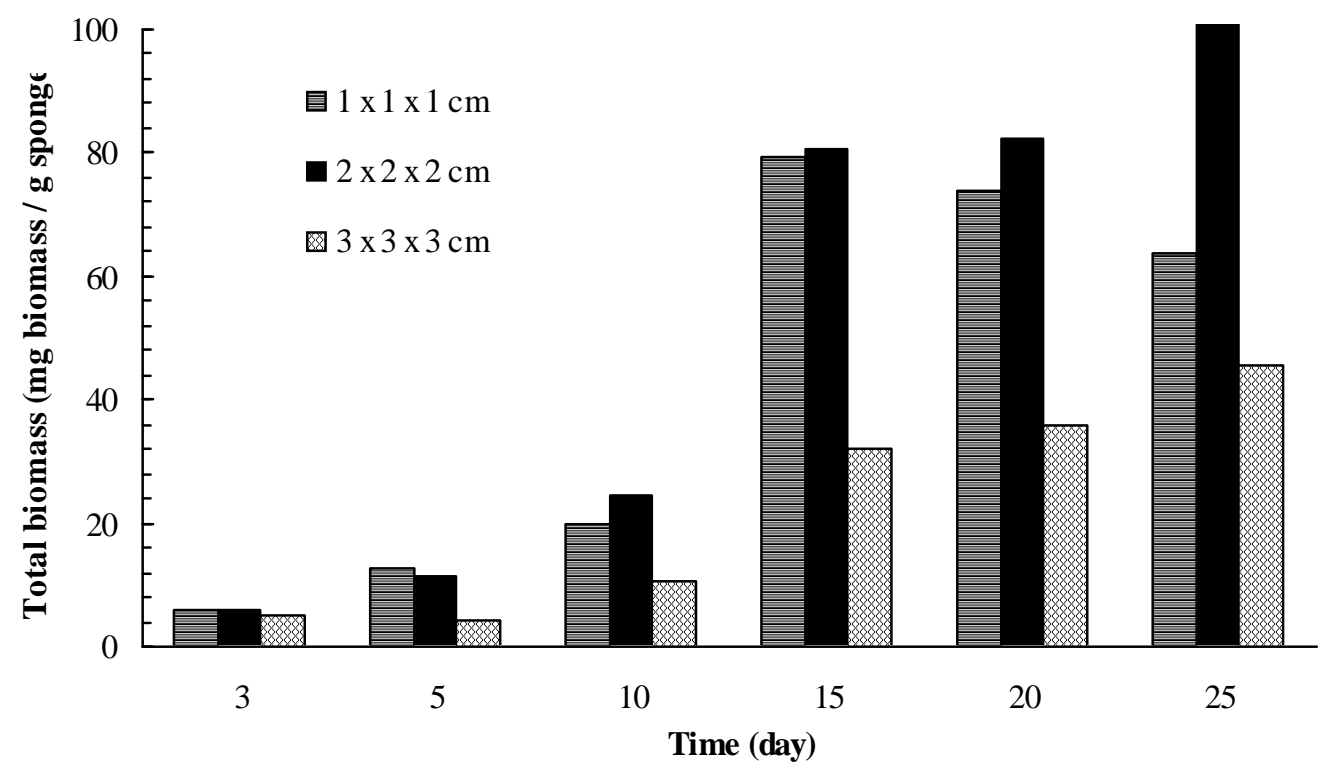

Fig. 3. Profiles of total biomass of sponge for different sizes of sponge (sponge volume $=430-432 \mathrm{~cm}^{3}$, influent feeding rate $=10 \mathrm{~mL} / \mathrm{min}$, organic loading rate $=11.05 \mathrm{~kg}$ $\mathrm{COD} / \mathrm{m}^{3} . \mathrm{d}$, hydraulic retention time $=2.62$ hours) 

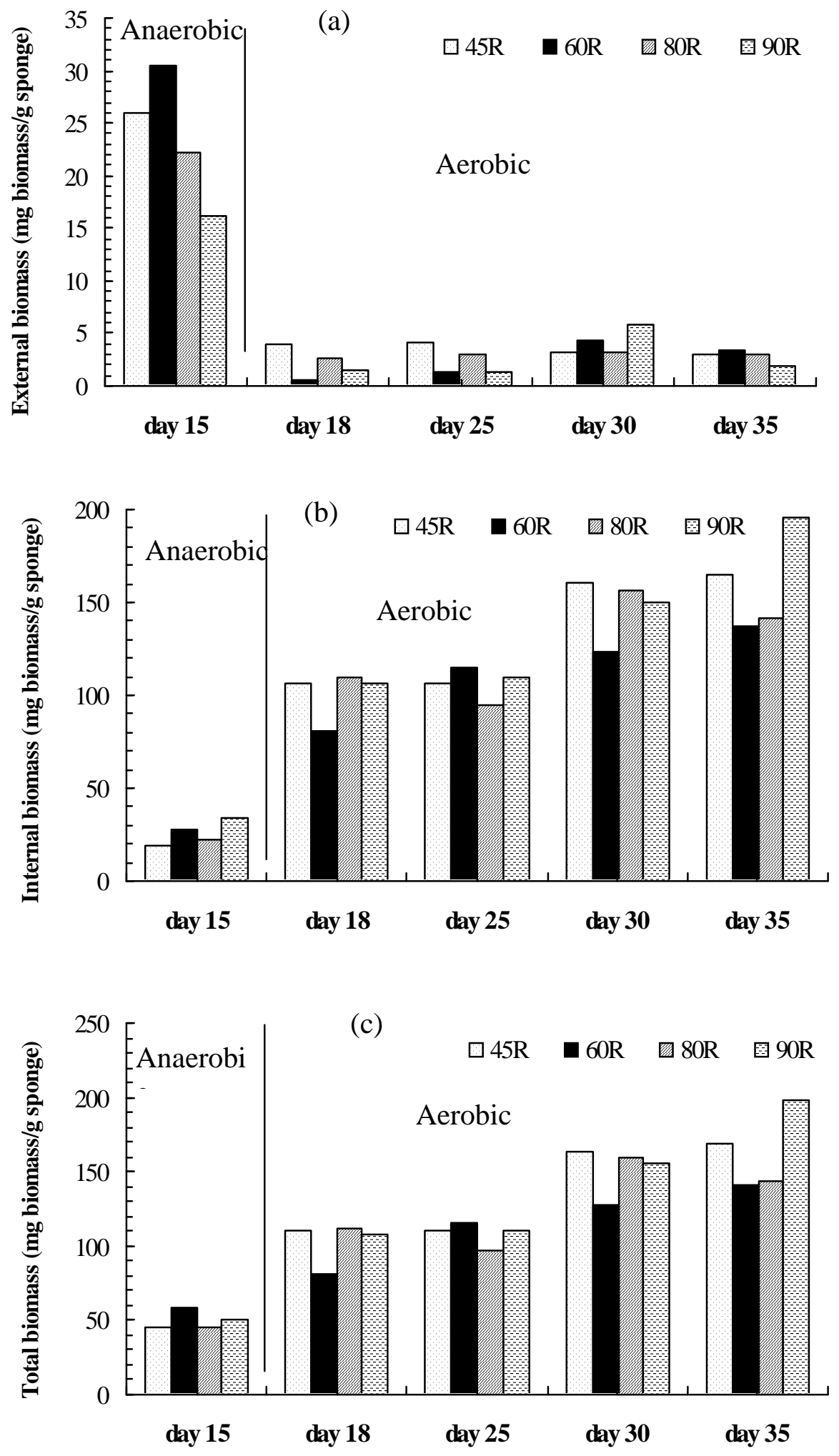

Fig. 4. Biomass variation for different types of sponge, (a) external biomass, (b) internal biomass, (c) total biomass (sponge size $=1 \times 1 \times 1 \mathrm{~cm}$, number of sponge in each reactor $=186$, influent feeding rate $=10 \mathrm{~mL} / \mathrm{min}$, organic loading rate $=11.05 \mathrm{~kg}$ $\mathrm{COD} / \mathrm{m}^{3} . \mathrm{d}$, hydraulic retention time $=2.62$ hours) 